\title{
Government Expenditure for Healthy Development: A Catch-22 for India
}

\author{
Dr. Shilpi Gupta ${ }^{1}$ \\ ${ }^{I}$.Associate Professor, Department of Economics, Manipal University Jaipur \\ shilpi.gupta@jaipur.manipal.edu,guptashilpi09@gmail.com
}

\begin{abstract}
For decades, economic growth and development have been highlighted in terms of increasing GNP. Recently the notion of growth has undergone a considerable shift from an increase in GNP to improvement in human development which is a target of Millennium Development Goals 2015. The main objective of MDGs 2015 is to strengthen the human resources of a nation that has been neglected in India for a long time. Implementation of government policies to achieve the targets of MDGs also has not been quite satisfactory. The purpose of this research is to explore the impact of government expenditure on HDI to take the economy towards the path of healthy development to realize MDGs 2015. Time series analysis has been used from 2000 to 2019 to investigate the reasons and facts by using OLS and unveil the facts related to human development expenditures.
\end{abstract}

Keywords: MDGs, Government Expenditure, HDI, Development Expenditure, Economic Growth, Economic Development

\section{INTRODUCTION}

The Indian economy has witnessed significant changes in the past few decades moving from bicycle to space crafts. If the achievements continue at the same pace India would emerge as a superpower in near future. The Indian economy has made enormous strides towards growth and development, but the darker side of this fact is that it has been significantly very slow in terms of human development. The development process concerning human development of any economy is a multidimensional phenomenon that includes the level of education, health, water, sanitation and family planning, the standard of living, access to communication, infrastructure, etc (Abhiman Das, 2000; Gupta S., Razmi J; 2012). Many economists (Baldacci E, Teresa. M Luizde M, 2003) developed the relationship between economic growth and human development and the same has been extended by the researchers to identify the new dimension of development i.e. healthy development comprising economic growth and human development. Although, increase in national income and per capita income is considered to be an effective indicator of economic growth but increase in Human Development Index could be considered as an indicator of healthy and sustainable development.
GDP at a constant price of Indian economy has increased from $13,47,889 \mathrm{Cr}$ in $1990-91$ to 57,41 , $791 \mathrm{Cr}$ and per capita income has increased from 2200 to 4000 US \$ over the period 2000-01 to 201314 (Economic survey, 2001-2018-19). But the status of HDI has not undergone any significant changes as clear from the fact that the average annual growth of HDI during 1990-91 to $1999-2000$ was 1.15 percent and during 2000-01 to 2018-19 (UNDP 2011) it is 1.49 percent. Presently India stands $131^{\text {th }}$ in HDI and has not improved for the past few years as compared to other developing nations. The figure of GDP shows that India has been driven towards the path of economic development but the value of HDI shows a different picture i.e. as the nation's moving towards economic growth \& development, the value of HDI is not improving at the same pace. To investigate and quantify the reasons the present paper has attempted to explore the shortcomings behind it.

\subsection{Objectives}

The primary objective of the present paper is to explore the impact of economic, social and political indicators on HDI of India towards healthy development and highlight the relationship between the government expenditure (GE) and HDI in one section along with the relationship between 
economic growth and HDI in other section. The secondary objective is to unveil the facts and facts behind the healthy and sustainable development of India.

\subsection{Challenges of India and Scope of the study}

India ranks second in terms of population after China and favorably enjoys abundant labor force and is also expected to enjoy the benefits of a growing population in future in terms of "Demographic Dividend". It is not only true that India would have the maximum working force but also the average age of the working population would be around 25 to 27 years, the youngest of all other nations. But the darker side of this aspect is if the human resource is not harnessed then the excess of the labor force would turn into dependent and result in mass unemployment, poverty, lower savings, and capital formation (Nanda et al., 2018, Samanta, 2018). It is therefore very important to make adequate investments in human resources to get it converted into human capital and improve India's rank in terms of HDI.

\subsection{Data and Model}

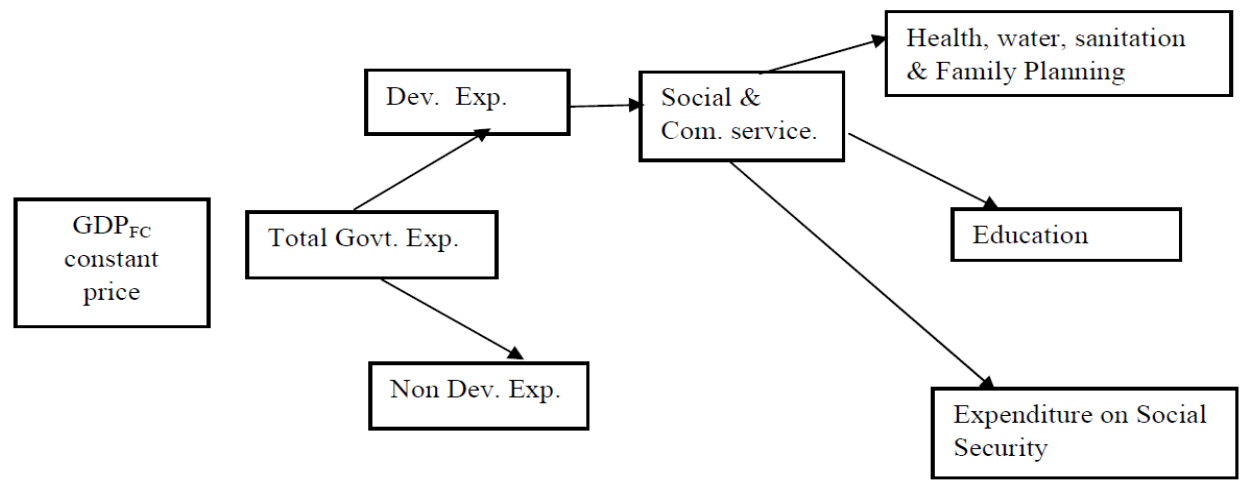

Figure 1.1- Data collection flow chart

This study is a descriptive analysis of the time series relationship between healthy development and GE on health, water, sanitation \& family planning, education, and social security from 2000 to 2019 (Moitahed A, S. Javadipoor 2003). This paper follows below mentioned flow chart for data collection (figure 1.1)

To achieve the above-said objectives of the study two models have been adopted to highlight the relationship between eight explanatory variables on HDI and the impact of HDI on economic growth.

Model 1 factor).

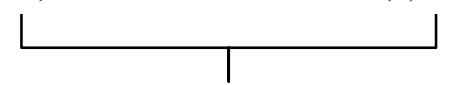

(A)

Here ruling party leader).
Healthy development of a nation that includes both societal and economic development can be achieved only through the active role of government. In this regard, the expenditure made by the government plays a very important role in the improvement of the HDI of developed and developing nations.

The present study aims to analyze the role of development expenditure (DE), non-development expenditure (NDE), and economic growth in the betterment of HDI. DE has various components like social community \& services (SC\&S), general economic services, fertilizers subsidy, transport and communication, public chart works, etc. With the aim of the research here to investigate the effect of development expenditure on HDI, two models have been constructed by the researchers using econometric tools like compound annual growth rate, correlation (H Sadeghi, A. Masaeli, M. Basakha, M. Kouhian 2010; Opereana Alim, Mihaiu Diana 2011) and regression using ten explanatory variables over the period 2000-01 to 2018-19. Secondary data has been compiled from the GOI department's various reports (Indian public finance statistics reports, Education Statistics; Health and Family welfare statistics, Economic Survey GOI, 2001; 20180-19)

The prosperity and healthy development of a nation $=f$ (Economic, Social factor, Political

$\mathrm{A}=\mathrm{f}$ (agriculture, infrastructure, industrial sectors, health, water, sanitation, family planning, education, social security, vision \& philosophy of 
(B)

$\mathrm{B}=\mathrm{f}$ (equipment and machinery, skilled manpower, management of natural resources, energy, banking and insurance, marketing, transport and communication facilities)

\section{(C)}

$\mathrm{C}=\mathrm{f}$ (Government Policies \& programmes, good governance, funds allocation, effective implementation of government policies, creating/reviewing/ adopting instruments for hastening the pace of development.

So,

The prosperity and healthy development of a nation $=\mathrm{f}(\mathrm{C})$

Therefore,

$\mathrm{HDI}=\beta_{1} \mathrm{Gr}+\beta_{2} \mathrm{E}_{\mathrm{DE}}+\beta 3 \mathrm{GE}_{\mathrm{S \& CS}}{ }^{+} \quad \beta_{4} \mathrm{GE}_{\mathrm{EDU}^{+}}+$ $\beta_{5} \mathrm{GE}_{\mathrm{HWS} \& \mathrm{FP}}+\beta_{6} \mathrm{GE}_{\mathrm{SS}}+\beta_{7} \mathrm{E}_{\mathrm{NDE}}$

Here,

$\beta_{1, \ldots . .} \beta_{7=}$ parameters to be estimated

$\mathrm{Gr}=$ GDP growth rate per capita

$E_{D E}=$ development expenditure

$\mathrm{GE}_{\mathrm{S} \& \mathrm{CS}}=$ government expenditure on social \& community service

$\mathrm{GE}_{\mathrm{EDU}}=$ government expenditure on education

$\mathrm{GE}_{\text {HWS\&FP }}=$ government expenditure on health, sanitation, water \& family planning

$\mathrm{GE}_{\mathrm{SS}}=$ government expenditure on social security

$\mathrm{E}_{\mathrm{NDE}}=$ non development expenditure

\section{Model- 2}

$\mathrm{Gr}=\alpha_{1} \mathrm{E}_{\mathrm{DE}}+\alpha_{2} \mathrm{E}_{\mathrm{NDE}}+\alpha_{3} \mathrm{HDI}$ VALUE

$\alpha_{1}, \alpha_{2}, \alpha_{3}=$ parameters to be estimated

$\mathrm{Gr}=\mathrm{GDP}$ growth rate per capita

$E_{D E}=$ development expenditure
$\mathrm{E}_{\mathrm{NDE}}=$ non development expenditure

HDI VALUE $=$ Value of HDI

\subsection{Model Estimation Results}

To prove some important results through this study, first stationarity has been tested among all the explanatory variables, and equations described in model-1 and model-2 are estimated by using OLS (Rout et al., 2018). The results of the present study are given in Table 1.1 and 1.2 respectively. Table 1.1 brings out the relationship between the explanatory variable and HDI whereas Table 1.2 highlights the relationship between explanatory variables on economic growth. The purpose of the study is basically to explore the relationship between the independent variables taken for the study (listed below) with HDI and economic growth. Table 1.1 highlights the fact that all the independent variables considered in the present study are strongly influencing the HDI of the Indian Economy since 2000.

It is seen in table 1.1 that GDP Per Capita, DE, SC\&S, education expenditure, health expenditure, and GDP at Factor Cost have a high significant positive correlation which is shown by R-value $(>0.75)$. The results of Durbin Watson test further indicates the absence of autocorrelation among that entire explanatory variable (as the values of DW test are $>1.2$ ). Finally, all the independent variables have shown a high level of significance implying that all the variables have a high influence on HDI (sig value $<.005$, except Social Security) of the Indian economy. Therefore, the results of the study in table 1.1 bring about the fact that an economy has to increase its DE comprising of education expenditure, health expenditure, and expenditure on social community and social security which would have a direct bearing on the improvement of HDI.

Table 1.1

\begin{tabular}{|c|c|c|c|c|c|c|c|c|c|c|c|c|c|c|}
\hline \multicolumn{2}{|r|}{ Dependent Variable-HDI } & \multirow{2}{*}{$\mathrm{R}$} & \multirow{2}{*}{$\mathrm{R}^{2}$} & \multirow{2}{*}{$\begin{array}{l}\text { Adj. } \\
\mathrm{R}^{2}\end{array}$} & \multirow{2}{*}{$\begin{array}{l}\text { SE of the } \\
\text { Esti. }\end{array}$} & \multirow{2}{*}{$\mathrm{dfl}$} & \multirow{2}{*}{ Df2 } & \multirow{2}{*}{$\begin{array}{l}\text { Sig. F } \\
\text { Chang } \\
\text { e }\end{array}$} & \multirow[t]{2}{*}{ D-W } & \multicolumn{2}{|c|}{ Unstd. Coff. } & \multirow{2}{*}{$\begin{array}{c}\text { Std. } \\
\text { Coef. } \\
\text { Beta } \\
\end{array}$} & \multirow{2}{*}{$\mathrm{t}$} & \multirow{2}{*}{ Sig. } \\
\hline & Independent variables & & & & & & & & & B & SE & & & \\
\hline 1 & GDP PER CAPITA & 0.781 & 0.61 & 0.578 & 0.1728422 & 1 & 12 & 0.001 & 1.608 & $\begin{array}{l}-.085 \\
.001\end{array}$ & $\begin{array}{l}.188 \\
.000\end{array}$ & .781 & $\begin{array}{l}-.450 \\
4.336\end{array}$ & $\begin{array}{l}.661 \\
.001\end{array}$ \\
\hline 2 & DEV. EXP & 0.755 & 0.57 & 0.534 & 0.1816101 & 1 & 12 & 0.002 & 1.57 & $\begin{array}{l}0.407^{*} \\
1.047\end{array}$ & $0.089 * 0$ & 0.755 & $\begin{array}{l}4.55^{*} \\
3.98\end{array}$ & $\begin{array}{l}0.001 * \\
0.002\end{array}$ \\
\hline 3 & SOCIAL \& CS & 0.768 & 0.59 & 0.556 & 0.177 & 1 & 12 & 0.001 & 1.54 & $\begin{array}{l}0.391^{*} \\
4.26\end{array}$ & $0.089 * 0$ & 0.768 & $\begin{array}{l}4.38^{*} \\
4.16\end{array}$ & $\begin{array}{l}0.001^{*} \\
0.001\end{array}$ \\
\hline 4 & EDU. EXP. & 0.756 & 0.572 & 0.536 & 0.1811424 & 1 & 12 & 0.002 & 1.504 & $\begin{array}{l}0.421^{*} \\
8.857\end{array}$ & $0.086 * 0$ & 0.756 & $\begin{array}{l}4.895^{*} \\
4.005\end{array}$ & $\begin{array}{l}0.001^{*} \\
0.002\end{array}$ \\
\hline 5 & HEALTH EXP. & 0.75 & 0.563 & 0.527 & 0.1830009 & 1 & 12 & 0.002 & 1.267 & $\begin{array}{l}0.434^{*} \\
2.453\end{array}$ & $0.085 * 0$ & 0.75 & $\begin{array}{l}5.127^{*} \\
3.934\end{array}$ & $\begin{array}{l}0^{*} \\
0.002\end{array}$ \\
\hline 6 & SOCIAL SEC. & 0.627 & 0.393 & 0.342 & 0.2157274 & 1 & 12 & 0.016 & 1.323 & $\begin{array}{l}0.605^{*} \\
0\end{array}$ & $0.068^{*} 0$ & 0.627 & $\begin{array}{l}8.895^{*} \\
2.787\end{array}$ & $\begin{array}{l}0^{*} \\
0.016\end{array}$ \\
\hline 7 & GDP FC at CONS. & 0.778 & 0.606 & 0.573 & 0.1739 & 1 & 12 & 0.001 & 1.599 & $\begin{array}{l}0.029^{*} \\
1.758\end{array}$ & $0.164 * 0$ & 0.778 & $\begin{array}{l}0.176^{*} \\
4.292\end{array}$ & $\begin{array}{l}0.863^{*} \\
0.001\end{array}$ \\
\hline 8 & NON-DEV. EXP. & 0.749 & 0.562 & 0.525 & 0.1833 & 1 & 12 & 0.002 & 1.423 & $\begin{array}{l}0.294^{*} \\
1.069\end{array}$ & $0.116 * 0$ & 0.749 & $\begin{array}{l}2.533^{*} \\
3.922\end{array}$ & $\begin{array}{l}0.026^{*} \\
0.002\end{array}$ \\
\hline
\end{tabular}


Source : Author's calculation

Further table 1.2 brings out the relationship between HDI, DE, and NDE on the economic growth of the nation (economic growth is computed based on GDP at FC at constant Prices).

The result brings the fact that all the three Independent variables have a significant influence on Table 1.2- The relationship between explanatory variable on Economic Growth

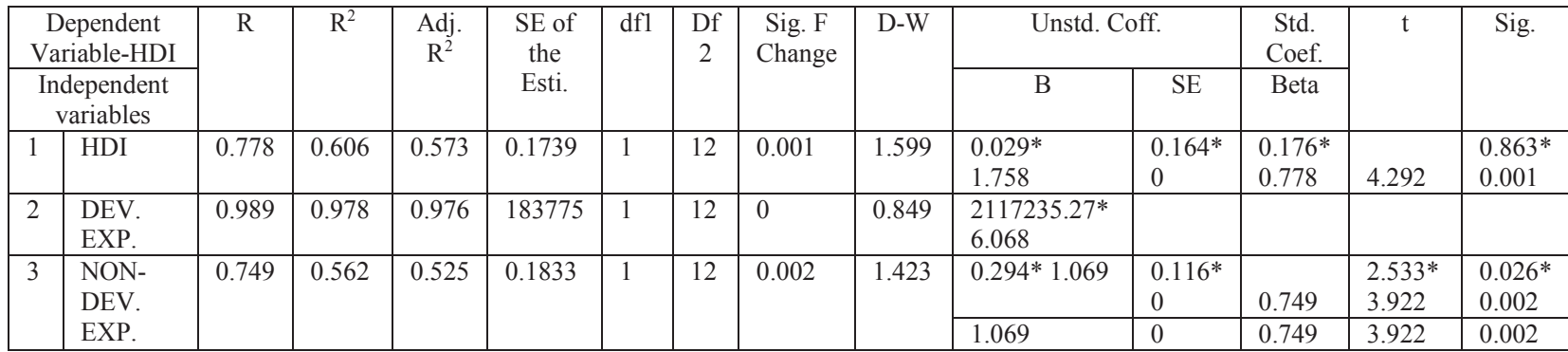

Source : Author's calculation

\section{SECTION II}

\subsection{Findings- Unveiling the reality of government expenditure towards healthy development}

Table 1.1 and 1.2 in section 2 advocated the rosy picture of India towards the path of healthy development. Is it a real healthy development? If we take a look at India's rank in terms of HDI since 2000 it has been found that India's status in terms of HDI has improved a little (presently holding 129th rank). This section of the paper would unveil the reality behind why India couldn't move ahead? This research highlights the facts and facto based on GDP, DE, and NDE along with various subheads. If we take a look at the CAGR of GDP at factor cost at the constant price it is 7.12 percent, CAGR of GDP at market price in terms of current price is 13.55 percent and that of total expenditure (TE) accounts to be 13.44 percent respectively. To go into deep sense research the CAGR of allocation of TE between DE and NDE are 3.11 percent and negative 1.85 percent, respectively (Figure-1.2).

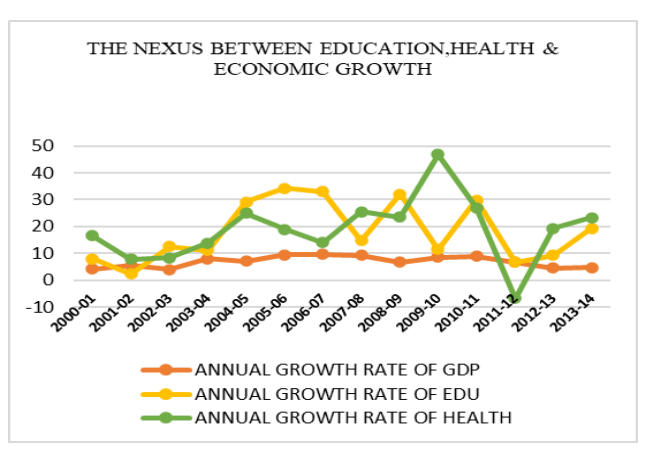

Figure-1.2 economic growth shown by R-value $>0.75$ but development expenditure has a strong positive correlation i.e. having the highest R-value of 0.99 . Therefore, the economic growth of any nation depends on HDI and especially DE of the economy.
The figures given above highlight the fact that GE towards healthy and sustainable development has shown a minor increment since 2000 .

Despite increasing DE for claiming better human development i.e. from 74,581 crore in $1999-2000$ to $6,18,980$ crore in 2018-19 which is almost 89 percent, whereas for the same period the value of HDI has improved just by $0.1(0.483$ to 0.583$)$. This brings out the fact that an increase in the DE in the past fifteen years has resulted in a very meager improvement in terms of HDI.

Henceforth, an attempt has been made by the researchers to throw light on those issues which play a vital role in the deviation from targets and real achievements (T\&A gaps). The following points given below would explore all the reasons for $\mathrm{T} \& \mathrm{~A}$ gaps.

SC\&S has been identified as an important factor contributing towards healthy and sustainable development. International studies have revealed the fact that expenditure on SC\&S especially health, education, and social security have a direct influence on HDI and therefore it is inevitable for an economy to allocate a major proportion of its $\mathrm{DE}$ for strengthening its human resources so as not only to improve the status of HDI but also to reap the benefits of 'demographic dividend'. It is also found that the CAGR of expenditure on SC\&S since 2000 is 12.17 percent which is just negative 0.7 percent of DE.

It has been identified in the present study that educational expenditure has increased with a CAGR of 7 percent which comprises only 1.2 percent of 
total development expenditure which is very low in comparison to other developing nations.

In the case of health expenditure, the annual growth rate has been recorded as 2.64 percent which is just 1.2 percent of $\mathrm{DE}$.

Finally, in the case of social security expenditure, the CAGR tends to be 21.11 percent whence it is negative 6.61 percent of DE.

\section{SECTION III}

\subsection{Suggestions, Recommendation and Conclusion}

The results of the present study highlight the effect of DE and NDE towards healthy development. Government expenditure as public good is used for the betterment of society both in terms of mental and physical growth. The results of empirical studies and calculation of this study show a positive and significant impact of GE on Human development. It is observed that the TE has increased by more than 4 times since 2000 (414.95 percent) whereas the allocation of total expenditure as a part of development among non-development expenditure has increased by more than 6 times (666 percent) more than 3 times (304.76 percent) respectively. Further, the allocation of DE in SC\&S increased by 6 times (599.47 percent). Similarly, the allocation of social \& community services expenditure on education, health \& social security has shown an increment of 800. 23 percent, 795.67 percent, and 215.12 percent, respectively. The figures show that the government is more concerned about taking off the economy toward the path of healthy development. As it has been discussed in section II, the annual growth of government expenditure under various subheads such as education, health, and social security services comprises only 1-2 percent of TE made by the government (Figure-1.3). In spite, the value of HDI has increased by just 0.01 in fourteen years.

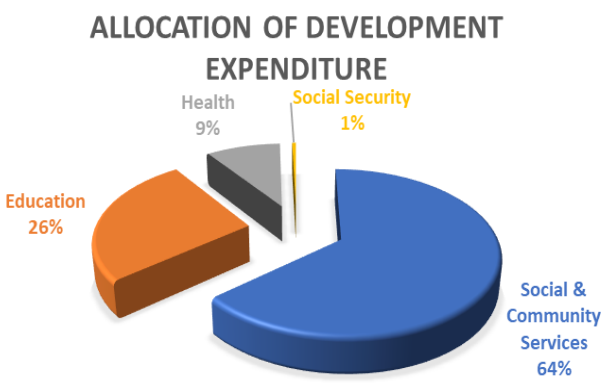

Figure-1.3

Source: Based on Author's calculation
This research has pointed out an issue stating that if government has an adequate amount of funds and has been allocating significantly for healthy development but there is no improvement seen in human development in India. Some recommendations are mentioned below.

The prosperity of nations not only depends upon the allocation of funds and framing of policies but also on the effective implementation of those for hastening the pace of healthy development (Rout et al., 2021).

Review of the policies and programmes must be undertaken at regular time intervals to assess the successes of such programmes.

Government should frame and follow effective economic models to quantify the results of the programmes simultaneously so that India can progress towards prosperity and healthy development.

\section{REFERENCES}

[1] Educational Statistics At A Glance Government of India Ministry of Human Resource Development Bureau of Planning, Monitoring \& Statistics New Delhi, various years

[2] Health and Family Welfare Statistics (2013) Ministry of Health and Family Welfare, Government of India

[3] S. Gupta (2012), "Political Economy of Human Development Expenditure of Rajasthan since 1980” IPE Journal Vol. 29 pp 45- 60.

[4] Md. J Razmi (2012) "Investigating the effect of Government Health Expenditure on HDI in Iran"

[5] Abhiman Das (2000) "Socio Economic Development India: A Regional Analysis", Development and Society, Vol 28, pp 313-345

[6] Baldacci Emanluele, Teresa Maria and Luizde Mello (2003), More on The Effectiveness of Public Spending on Health Care And Education, Journal of International Development, Dev. 15, 2003.

[7] H Sadeghi, A Masaeli , M Basakha and M Kouhian (2010), The Estimation of HDI for Provinces, Social Welfare Quarterly, vol.37.

[8] S. Samanta, Social Entrepreneurship Promoting Inclusivity, Empowerment and Participative Governance-A Bibliographic Insight, The 
Indian Journal of Commerce 71 (03 \& 04) (2018) 34-48.

[9] P.K. Raut, J. R. Das, J. Gochhayat, K. P. Das, Influence of workforce agility on crisis management: Role of job characteristics and higher administrative support in public administration, Materials Today: Proceedings (2021).

https://doi.org/10.1016/j.matpr.2021.08.121.

[10] Mojtahed Ahmad, Saeed Javadipoor (2003), An Analysis of the Effect of Health Expenditures on Economic Growth in Selected Developing Countries, Iranian Journal of Economic Research (Text in Persian), Issue 19, Page 31.

[11] Opreana Alin, Mihaiu Diana Marieta (2011), Correlation Analysis Between the Health System and Human Development Level Within the European Union, International Journal of Trade, Economics and Finance, Vol.2, No.2, April 2011.
[12] S.S. Rout, B.B. Misra, S. Samanta, Competency mapping with Sugeno fuzzy inference system for variable pay determination: A case study, Ain Shams Engineering Journal, 9 (4) (2018) 2215-2226. https://doi.org/10.1016/j.asej.2017.03.007.

[13] A.K. Nanda, S. Samanta, Mainstreaming tribals through financial literacy - a review of literature, International Journal of Social

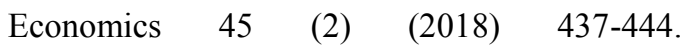
https://doi.org/10.1108/IJSE-12-2016-0371

[14] UNDP (2011), Human Development Report, New York : Oxford university press.

[15] Economic survey, Planning Department, Government of India, various years

[16] Indian Public Finance Statistics, Ministry of Finance, Department of Economic Affairs, Government of India, various years 